\title{
PROBLEMATIKA PEMBELAJARAN KEMAMPUAN MENYIMAK BAHASA JERMAN SISWA KELAS XI SMAN 11 MAKASSAR
}

\author{
Agnes Rapi Pabumbun' ${ }^{1}$ dan Ambo Dalle ${ }^{2}$ \\ Fakultas Bahasa dan Sastra, Universitas Negeri Makassar \\ E-mail ${ }^{1}:$ rapiagnes@yahoo.co.id ${ }^{1}$
}

\begin{abstract}
ABSTRAK
Penelitian ini bertujuan untuk mendeskripsikan masalah-masalah pembelajaran kemampuan menyimak bahasa Jerman siswa kelas XI SMA Negeri 11 Makassar. Pengambilan data pada penelitian ini menggunakan teknik observasi, wawancara terhadap guru dan menyebarkan angket kepada siswa. Populasi dalam penelitian ini adalah siswa kelas XI SMA Negeri 11 Makassar, yang terdiri dari siswa 33 siswa. Wawancara dilakukan dengan dua guru. Hasil yang diperoleh pada penelitian ini yaitu masalah-masalah yang dihadapi dalam proses pembelajaran meliputi masalah internal dan eksternal. Masalah internal meliputi penguasaan aspek kebahasaan lainnya, minat, persepsi, fisik, dan psikologis sedangkan faktor eksternal meliputi Lingkungan, guru, bahan ajar, sarana dan prasarana.
\end{abstract}

Kata Kunci: Problematika, Kemampuan Menyimak

\begin{abstract}
This study aimed to describe the problem to learning ability listening Germany skills class XI student of SMAN 11 Makassar. Collecting data in this study using observation, interviews and questionnaires. The population in this study is a class XI student of SMAN 11 Makassar, which is comprised of students 33 students. Interviews were conducted by two teachers. The results obtained in this research that the problems encountered in the learning process includes internal and external problems. Internal issues include the control of other aspects of language, interests, perceptions, physical, and psychological. while external factors include the environment, teachers, teaching materials, facilities and infrastructure.
\end{abstract}

Keywords: Problems, Listening Capabilities

\section{PENDAHULUAN}

Pendidikan bahasa yang diperoleh di sekolah memiliki peran penting dalam kehidupan bermasyarakat. Bahasa asing dalam kedudukannya sebagai ilmu pengetahuan memiliki peran penting yaitu sebagai alat komunikasi. Bahasa asing dapat memberikan peluang untuk berkomunikasi dengan masyarakat di negara lain. Bahasa Jerman memilki peminat yang tergolong banyak dan dijadikan sebagai mata pelajaran peminatan. Selain itu pembelajaran Bahasa Jerman memiliki empat kompetensi dan dua penunjang. Terdapat berbagai potensi kesulitan dalam proses pembelajaran menyimak bahasa Jerman. Pembelajaran menyimak bahasa Jerman memiliki tambahan huruf umlaut juga pengucapannya yang cenderung berbeda pada huruf konsonan dan huruf vokal mengakibatkan siswa harus berusaha beradaptasi dengan 
setiap kata yang mengandung huruf umlaut. Faktor dari luar juga berpotensi menjadi masalah yang menghambat proses pembelajaran seperti fasilitas laboratorium bahasa yang tidak digunakan secara maksimal dan berbagai masalah-masalah yang menjadi kendala siswa maupun guru untuk menunjang kemampuan menyimak bahasa Jerman.

Ghufron (2014) yang menyatakan "Problematika pengajaran bahasa asing di Indonesia dapat dikategorikan ke dalam tiga hal, yaitu: problem linguistik, problem metodologis dan problem sosiologis.

\section{HAKIKAT PROBLEMATIKA}

Menurut Syukir

(1983:65)

"problema/problematika adalah suatu kesenjangan antara harapan dan kenyataan yang diharapkan dapat menyelesaikan atau dapat diperlukan atau dengan kata lain dapat mengurangi kesenjangan itu."

Sugiyono (2012: 29) menyatakan bahwa "Masalah merupakan penyimpangan dari apa yang seharusnya dengan apa yang terjadi, penyimpangan antara teori dan praktik, penyimpangan aturan dan pelaksanaan dan penyimpangan yang terjadi pada masa lampau dengan yang terjadi sekarang" problematika adalah hal yang masih menimbulkan masalah yang belum dapat dipecahkan.

Berdasarkan pendapat diatas, dapat disimpulkan bahwa problematika merupakan masalah yang timbul akibat adanya kesenjangan antara harapan dan kenyataan sebagai suatu halangan pada sebuah proses.

\section{PEMBELAJARAN}

Pembelajaran merupakan proses
untuk memperoleh ilmu pengetahuan.
Menurut Rachmawati dan Daryanto (2015:
81) "pembelajaran ialah suatu proses yang dilakukan oleh individu untuk memperoleh suatu perubahan tingkah laku yang baru secara keseluruhan, sebagai hasil dari pengalaman individu itu sendiri dalam interaksi dengan lingkungannya."

Menurut Trianto (2009), Nurmi (2017) pembelajaran merupakan aspek kegiatan manusia yang kompleks, yang tidak sepenuhnya dapat dijelaskan. Berdasarkan makna ini jelas terlihat bahwa pembelajaran merupakan interaksi dua arah dari seorang guru dan peserta didik, dimana antara keduanya terjadi komunikasi (transfer) yang intens dan terarah menuju pada suatu target yang telah ditetapkan sebelumnya. Berdasarkan pendapat beberapa ahli diatas, dapat disimpulkan bahwa pembelajaran merupakan proses mendapatkan ilmu pengetahuan untuk mendapatkan tujuan tertentu.

Menurut Mager dalam Rachmawati dan Daryanto (2015:7) mengemukakan bahwa "tujuan pembelajaran adalah perilaku yang hendak dicapai atau yang dapat dikerjakan oleh peserta didik pada kondisi dan tingkat kompetensi tertentu."

Sudrajat (2009:1) memberikan rumusan "tujuan pembelajaran yang beragam, tetapi semuanya menunjuk pada esensi yang sama, bahwa: (1) tujuan pembelajaran adalah tercapainya perubahan perilaku atau kompetensi pada peserta didik setelah mengikuti kegiatan pembelajaran; (2) tujuan dirumuskan dalam bentuk pernyataan atau deskriptif yang spesifik." Berdasarkan pendapat ahli diatas, dapat disimpulkan bahwa tujuan pembelajaran adalah pencapaian yang diharapkan dalam proses pembelajaran. 


\section{KEMAMPUAN MENYIMAK}

Kemampuan merupakan segala upaya yang dapat diakukan baik secara fisik maupun mental. Kushartanti (2005:216) mengungkapkan bahwa "kemampuan adalah pengetahuan tentang bahasa yang ada di dalam akal dan budi seseorang”.

Pendapat lain yaitu Soelaiman (2007:112) yang menyatakan bahwa "kemampuan adalah sifat yang di bawa lahir atau dipelajari yang memungkinkan seseorang yang dapat menyelesaikan pekerjaannya, baik secara mental ataupun fisik"

Menyimak merupakan proses mendengarkan dengan penuh pemahaman dan apresiasi. Menurut Tarigan (2008:28) "Menyimak adalah suatu proses kegiatan mendengarkan lambang-lambang lisan dengan penuh perhatian, pemahaman, apresiasi serta interpretasi untuk memperoleh informasi, menangkap isi atau pesan serta memahami makna komunikasi yang telah disampaikan oleh sang pembicara melalui ujaran atau bahasa lisan."

- Russel dan Russel dalam Tarigan (2008: 82-86) "menyimak bermakna mendengarkan dengan penuh pemahaman dan perhatian serta apresiasi."

Berdasarkan pendapat ahli di atas, dapat disimpulkan bahwa menyimak merupakan kegiatan mendengarkan lambanglambang lisan disertai dengan pemahaman dan apresiasi.

\section{METODE PENELITIAN}

Jenis penelitian deskriptif kualitatif yang digunakan pada penelitian ini dimaksudkan untuk memperoleh informasi mengenai masalah-masalah dalam pembelajaran menyimak bahasa Jerman
Data yang digunakan dalam penelitian ini adalah Data kualitatif, yaitu data yang disajikan dalam bentuk kata verbal bukan dalam bentuk angka.yang termasuk data kualitatif dalam penelitian ini yaitu gambaran umum obyek penelitian, meliputi: kondisi sekolah, kondisi pada saat berlangsungnya proses pembelajaran, keadaan guru, keadaan siswa, keadaan sarana dan prasarana

Pada penelitian kualitatif yang menjadi intrumen yaitu peneliti itu sendiri. pengumpulan data yang digunakan, maka instrumen penelitian ini menggunakan panduan wawancara dan panduan observasi serta di dukung oleh angket.

Teknik pengumpulan data dalam penelitian ini terdiri dari observasi, wawancara dan kuesioner. Observasi yang dimaksud untuk mengamati lingkungan sekitar, situasi, pola interaksi, dan tingkah laku siswa selama berlangsungnya pembelajaran menyimak bahasa Jerman.

Wawancara mendalam dilakukan untuk untuk mengetahui masalah-masalah pembelajaran menyimak bahasa Jerman yang dirasakan oleh subjek penelitian yang dapat memberikan gambaran konkret tentang maalah menyimak Bahasa Jerman.

Angket sebagai data penunjang yang memberikan temuan tentang meliputi kesan siswa terhadap pembelajaran, dan pengalaman berkegiatan pembelajaran kemampuan menyimak, dan penghambat dalam pembelajaran menyimak bahasa Jerman.

\section{HASIL DAN PEMBAHASAN .}

\section{Tempat, Waktu, dan Fasilitas Sekolah}

Ruangan yang cenderung terbuka dengan banyaknya jumlah jendela membuat suara yang yang berasal dari luar ruangan menjadi terdengar sehingga mengganggu 
proses pembelajaran. Terdapat pula masalah yang disebabkan oleh posisi tempat duduk, yaitu pada saat pagi hari terdapat pantulan sinar matahari di papan tulis sehingga dibeberapa bagian tempat duduk siswa menjadi tidak efektif melihat kearah depan dikarenakan mata yang menjadi silau. Tidak terdapat fasilitas dalam kelas yang menunjang secara spesifik pembelajaran kemampuan menyimak bahasa Jerman. Selain itu fasilitas sekolah seperti laboratotium bahasa yang penggunaannya tidak secara efisien karena jarang digunakan bahkan terdapat kelas yang tidak pernah belajar bahasa Jerman di dalam laboratorium bahasa.

Durasi waktu pembelajaran untuk pembelajaran menyimak bahasa Jerman sesuai dengan data yang berasal dari subjek penelitian sudah tergolong cukup sehingga tidak menimbulkan ketimpangan. Data yang bersumber dari siswa juga sudah mengganggap waktu dalam pembelajaran bahasa Jerman cenderung sesuai dengan kebutuhan, waktu pembelajaran yang lama dapat memicu kebosanan yang menimbulkan siswa menjadi tidak konsentrasi pada pembelajaran menyimak bahasa Jerman, sedangkan waktu yang singkat dapat menimbulkan ketidakpahaman siswa pada materi yang diajarkan karena ketidakefektifan durasi waktu. Kaitannya dengan waktu pembelajaran dapat menyebabkan tiap kelas yang berbeda juga menimbulkan masalah tersendiri, seperti kelas yang mendapat giliran belajar bahasa Jerman pada pagi hari dapat berpotensi lebih berkonsentrasi dibandingkan dengan pembelajaran bahasa Jerman di kelas yang jadwal belajarnya siang hari ataupun menjelang waktu pulang sekolah, konsentrasi siswa menjadi terpecah dan cenderung tidak fokus karena lelah pada pelajaran sebelumnya.

\section{Guru Mata Pelajaran Bahasa Jerman}

Metode yang sering digunakan guru dalam proses pembelajaran menyimak bahasa Jerman yaitu pemberian tugas, Hören und Sprechen, Gruppenarbeit, dan metode ceramah. Guru kerap kali meningkatkan minat bahasa Jerman siswa dengan memotivasi sebelum belajar selain itu yang kerap kali dilakukan oleh guru yaitu menambah wawasan siswa tentang kultur Jerman sehingga siswa lebih termotivasi dan tertarik mempelajari tentang bahasa Jerman, guru juga mempersilahkan dan menganjurkan siswa untuk mencari referensi kebudayaan Jerman melalui internet, hal tersebut didukung oleh sekolah yang menyediakan wifi, sehingga siswa dapat dengan mudah mengakses internet. Guru memberikan teguran pada siswa yang kurang perhatian pada saat proses pembelajaran bahasa Jerman karena ribut dan malas mencatat pada saat proses pembelajaran. Guru cenderung memberikan permainan atau games kepada siswa untuk memecahkan kejenuhan siswa sehingga siswa lebih bersemangat dalam proses pembelajaran menyimak bahasa Jerman.

\section{Kegiatan pembelajaran}

Secara keseluruhan kegiatan pembelajaran menyimak bahasa Jerman belum dapat dikatakan maksimal karena masih terdapat kekurangan terutama pada sarana dan prasarana yang tidak menunjang proses pembelajaran. selain itu proses menyimak bahasa Jerman belum dapat secara maksimal dikarenakan situasi belajar yang belum efektif.

\section{Materi Pembelajaran}

Materi pembelajaran yang terdapat di SMA Negeri 11 Makassar cenderung kurang 
karena sumber materi berupa buku tidak dimiliki oleh keseluruhan siswa. Selain itu sumber informasi mengenai pembelajaran bahasa Jerman yang masih tergolong minim untuk ditemukan, menunjukkan kurangnya potensi materi untuk dikembangkan. Pemberian tugas pada pembelajaran bahasa Jerman tidak berdampak siknifikan pada pengembangan ilmu pengetahuan bahasa Jerman siswa, hal tersebut dikarenakan masih maraknya budaya mencontek di kalang pelajar menimbulkan hanya sebagian kecil siswa yang memahami materi pembelajaran menyimak bahasa Jerman. Selain itu tidak adanya variasi metode pembelajaran menyimak membuat siswa cenderung jenuh.

\section{Media Pembelajaran}

Media pembelajaran yang masih tergolong minim dapat ditinjau dari kurangnya buku pegangan. Kurangnya siswa yang memiliki buku penunjang bahasa Jerman menjadi kendala dalam proses pebelajaran terutama sekolah tidak menjual buku paket bahasa Jerman sebagai penunjang, buku bahasa Jerman yang tersedia di perpustakaan sekolah juga tidak dapat mencangkup kebutuhan seluruh siswa karena tidak seimbangnya jumlah buku dengan jumlah siswa yang lebih banyak.

Laboratorium bahasa yang ada di sekolah tidak digunakan secara maksimal dikarenakan earphone yang tidak berfungsi dengan baik dan jumlah siswa dalam satu kelas yang lebih banyak dibandingkan dengan jumlah earphone dalam kelas bahasa.

\section{Proses Pembelajaran}

Kesulitan siswa memahami bahasa Jerman terutama dalam pembelajaran menyimak bahasa Jerman dikarenakan penguasaan akan huruf umlaut yang belum dikuasai siswa disertai dengan interferensi bahasa Inggris dan bahasa Indonesia dalam proses pembelajaran. Siswa yang tidak fokus dalam proses pembelajaran menyimak bahasa Jerman dikarenakan siswa yang fokus bermain handphone dalam pembelajaran sehingga untuk mengantisipasinya guru mengumpulkan handphone saat pembelajaran menyimak bahasa Jerman.

Berdasarkan temuan di lapangan bahwa siswa tidak dapat mengikuti pembelajaran menyimak bahasa Jerman dengan efektif dalam kondisi sakit maupun dalam kondisi tubuh yang menurun. Berdasarkan penjelasan tersebut, dapat disimpulkan bahwa kondisi fisik yang menurun dapat mempengaruhi siswa dalam proses pembelajaran menyimak bahasa Jerman.

\section{Minat}

Data uraian observasi menyatakan kurangnya motivasi siswa masih fokus pada hal lain seperti gadget atau bercerita dengan temannya saat proses pembelajaran sedang berlangsung sehingga menyiratkan siswa masih kurang minat dalam proses belajar selain itu berdasarkan hasil wawancara dengan guru menyatakan minat dan antusias siswa yang kurang pada pembelajaran bahasa Jerman dikarenakan kurangnya sumber pembelajaran yang menunjang. Selain itu kurangnya motivasi siswa untuk mencari dan mengembangkan bahasa Jerman melalui internet. Padahal, sekolah telah memfasilitasi melalui pengadaan wifi di sekolah. Dapat disimpulkan siswa memiliki minat pada pembelajaran bahasa Jerman tapi minat dan antusias siswa terhalang oleh beberapa faktor yaitu sumber belajar yang kurang dan kondisi kelas.

\section{Motivasi}

Berdasarkan uraian wawancara dengan guru dapat diketahui kurangnya motivasi siswa dikarenakan oleh pandangan siswa 
tentang penggunaan bahasa Jerman di kalangan masyarakat yang masih tergolong kurang dan tidak fungsional, guru memotivasi siswa dengan cara memberikan pandangan tentang budaya Jerman. Berdasarkan hasil observasi siswa terlihat belum antusias pada pembelajaran bahasa Jerman, siswa yang acuh tak acuh merespon guru yang sedang menjelaskan. Berdasarkan uraian tersebut, dapat disimpulkan bahwa motivasi siswa belum maksimal dalam proses pembelajaran bahasa Jerman disebabkan oleh beberapa faktor salah satunya pandangan tentang fungsi bahasa Jerman di masyarakat.

\section{Persepsi}

Hasil observasi siswa, lebih dari setengah siswa meminta guru mengulangi kembali penjelasannya. Berdasarkan hasil wawancara dengan guru siswa masih kurang paham bahasa Jerman terutama dalam kaitannya dengan penguasaan huruf umlaut dan interferensi bahasa Inggris sehingga siswa tidak memahami dengan baik menyimak bahasa Jerman. Berdasarkan uraian tersebut dapat disimpulkan bahwa persepsi siswa tentang bahasa Jerman masih cenderung kurang.

Kesempatan untuk Mendengarkan Bahasa Jerman

Kurangnya kebiasaan siswa untuk mendengarkan bahasa Jerman sesuai dengan temuan pada data angket tentang intensitas penggunaan bahasa Jerman dalam kehidupan sehari hari siswa masih jarang, siswa juga jarang berkomunkasi dengan native speaker, tetapi siswa belajar dengan teman sebaya untuk menanggulangi kesulitan menyimak bahasa Jerman. Hal tersebut didukung oleh hasil wawancara dengan guru yang menyatakan sumber informasi siswa masih kurang untuk memperoleh sumber pembelajaran menyimak bahasa Jerman. Hal serupa juga tergambar pada observasi yang memperlihatkan siswa cenderung bertanya atau berkomunikasi dengan teman saat tidak mengerti pembelajaran yang guru jelaskan.

\section{KESIMPULAN}

Hal yang mempengaruhi pembelajaran menyimak bahasa Jerman siswa kelas XI SMA Negeri 11 Makassar ditinjau dari faktor internal dan eksternal. Faktor internal terdiri atas penguasaan aspek kebahasaan lainnya yang kurang dikuasai siswa, minat siswa yang kurang, kondisi fisik siswa, persepsi siswa terhadap pembelajaran menyimak bahasa Jerman dan kondisi psikologis siswa. Faktor eksternal terdiri atas kondisi Lingkungan, guru,bahan ajar, sarana dan prasarana.

\section{DAFTAR PUSTAKA}

Bakri, Andi Hariyana. 2001. Kendala Pengajaran Sastra Indonesia di SMP Negeri 1 Pammana Kabupaten Wajo". Skripsi. Makassar: FBS Universitas Negeri Makassar.

Brown, H. Doulas. 2001. Teaching by Principles An Interactive Approach to Language Pedagogy. New York: Longman.

Farhan, ahmad sudaryanto. 2013. Analisis Kesulitan Menyimak Mahasiswa Semester 2 Prodi Pendidikan Bahasa Jepang. Skripsi: universitas negeri semarang.

Fitriana, Milkha. 2013. Upaya Peningkatan Kemampuan Menyimak Bahasa Jerman Kelas XII IPA SMA Negeri 7 Yogyakarta Tahun Ajaran 2012/2013 Melalui Media Audio dan Audio Visual. Skripsi. Yogyakarta: Fakultas Bahasa dan Seni Universitas Negeri Yogyakarta.

Ghufron, Muhammad Fuad. 2014. Problematika Pelaksanaan 
Pembelajaran Bahasa Arab terhadap Tuna netra di "Sekolah Inklusi" Madrasah Aliyah Negeri (MAN) Maguwoharjo Depok Sleman Yogyakarta”. Skripsi. Yogyakarta :Universitas Negeri Islam Kalijaga Yogyakarta.

Haling, dkk. 2007. Belajar dan Pembelajaran. Makassar :Badan Penerbit Universitas Negeri Makassar.

Hidayat, Fahmi. 2012. Kemampuan Menyimak (Hören)Siswa Kelas XI SMA Negeri 6 Malang. Skripsi. Malang: Universitas Negeri Malang

Kushartanti. 2005. Pesona Bahasa. Jakarta : Gramedia Pustaka Utama.

Marlina, Sandra Dewi. 2007. Penggunaan Media Bonek Kaos Kaki dalam Pembelajaran Menyimak Dongeng. Skripsi. Bandung: Universitas Pendidikan Indonesia.

Nurmiati, N., \& Mantasiah, R. 2017. Keefektifan Penggunaan Metode Pembelajaran Tutor Sebaya (PeerTeaching) Dalam Kemampuan Membaca Memahami Bahasa Jerman Siswa Kelas XI IPA SMA Negeri 1 Bontonompo Kabupaten Gowa. Eralingua: Jurnal Pendidikan Bahasa Asing dan Sastra, 1(1).
Purwandidan Suwandono. 2000. Menyimak Bahasa Indonesia. Surakarta :Universitas Sebelas Maret.

Satkauskait, Danguol. 2010. Zur Fertigkeit des Hörverstehens im DaFUnterricht und bei der Vermittlung der Dolmetschkompetenzen. Kalbu Studijos.

Soekamto, soerjono. 2005. Perspektif Teoritis Studi Hukum dalam Masyarakat.Jakarta: Rajawali press.

Subyantoro dan Bambang Hartono. 2003. Pengembangan Kemampuan Berbahasa Pembelajaran Keterampilan Mendengarkan, Berbicara, Membaca, dan Menulis. Makalah Disampaikan pada PelatihanTerintegrasi Berdasarkan Kurikulum Berbasis Kompetensi Tahun 2003.

Sudrajat, Akhmad. 2009. Tujuan Pembelajaran Sebagai Komponen Penting dalam Pembelajaran. Jakarta.

Tarigan, Henry Guntur. 1994. Menyimak sebagai Suatu Keterampilan Berbahasa. Bandung :Angkasa.

2008. Menulis
Keterampilan
Bandung:Angkasa.

Trianto.2009. Mendesain Model Pembelajaran Inovatif-Progresif. Jakarta: Kencana Prenada Media Group. 